\title{
Beyond meaning: Prospections of Suprematist semiotics
}

\section{Transcendence}

Transcendence: the mere word depicts an obstacle, a barrier, a fence; but also a passage. It establishes a difference, or at least a polarity, but installs, at the same time, a relation. Representing a "beyond" is so natural to human beings that rarely do they pay attention to it. Nevertheless, it might be a unique capacity, acquired thanks to tortuous evolutionary paths (Leone 2012a). Zoo-semiotics suggests that many living species, perhaps all of them, are endowed with signaling systems (Sebeok 1990). Bees-it has been known for a while-are able to indicate with precision the distance of a source of pollen, the right direction to reach it (Frisch 1965). It is, however, doubtful that they could deny such a message; communicate to the other worker bees that "no, there is no pollen there"; that capacity has to be searched for elsewhere. If future research will discover this faculty also in non-human animals, we humans will feel even closer to them (Maran, Martinelli and Turovski 2011). Indeed, negation is the indispensable prerequisite of "beyond." In order to think of a "beyond," one must not only represent to oneself a "here," but also negate it. The same goes for a "then," i.e., time that is distant in the past or in the future. The same goes for someone or something that is different from us and opposes us. All natural languages, it seems, feature negation operators, which allow humans to negate a mental state: I am not here; I am elsewhere (Horn 2001).

One can speculate on the paleontological context that led to such ability (Leone 2012d). Imagining dangers and opportunities in the environment, rather than experiencing them immediately and directly, must have bestowed an extraordinary advantage upon those endowed with such capacity. I need not see predators before fleeing them, prey before chasing it. I imagine them. But an even greater advantage must have been conferred by awareness that these mental images might not correspond to reality. The whole science originates from this negative imagination, from the faculty of comparing mental maps so as to determine which one is faithful to the state of things, and which one is not. It is an essential human capacity. It allows prisoners, or activists under torture, to project themselves outside of a cell (Leone 2013a). When torture breaks this capacity, it extinguishes humanity. There emerges the robot, a castrated conscience insofar as it is nailed to its conditions. Imagination, on the contrary, results from this natural 
inclination to negate actuality in order to construct potentiality. Willingness to pursue it coincides, then, with utopia, which also etymologically is a "nonplace" (from Greek ou + topos).

But what does "beyond" semiotically mean? The reader, especially the Western one, will immediately think about the concepts of "the divine," "the numinous," or at least "the metaphysical"; about a different ontology, detached from reality, separated from it by a limit that only religions, or spirituality, promises to cross: through asceticism, incarnation, revelation, or through the other operations that, by means of different signs, trace the opening of a passage between transcendence and immanence. A "rhetoric of beyond," however, exists in religion (Leone 2014a) as well as in not strictly religious phenomena. A common genealogy can be surmised. The faculty of negation, indeed, would be essential not only so as to distance a metaphysical transcendence, and narrate its contact with "the immanent," but also so as to generate the infinite "quotidian transcendences" that, in every time, culture, and place, outline a "map of the beyond" and substantiate the human capacity for the symbolic.

The etymology of "transcendence" admits this variety by simply indicating a movement. "To transcend" is to reach a place beyond an obstacle: a place in which one is not, which cannot be experienced through the senses, which can be only imagined and known through signs. Positing transcendence, therefore, requires awareness of the "I/we-here-now"-at least in the Indo-European linguistic domain-but it also requires an obstacle, or simply a limit. In Christian transcendence, such limit is the sky, or death. Only Revelation, in the Old Testament, or Incarnation, in the New Testament, put earth and heaven, life and death in constant communication.

Quotidian transcendences do not outline metaphysical but phenomenological watersheds. Negating an actual state in order to conceive potentiality is tantamount to creating difference and, therefore, meaning. Saussure (1972) perfectly explained this process. But negating means also igniting the flame of narration, constructing a slope, a tension, and a polarity. It is only through negating the existent, and through marking the limit that separates it from "a beyond," that the machinery of the tale is installed. Narration (or, better, "narrativity"), from this point of view, is nothing but the attempt at fueling meaning through such tension, by constructing a dam and, at the same time, channels to cross it (Greimas $1970-83)$.

But what is the relation between Transcendence and transcendences, between religious or spiritual discourses that project a metaphysical horizon-together with total otherness beyond it-and the infinite "narrations of beyond" that outline, like impetuous arteries or tiny capillaries, the very dense network of everyday meaning surrounding individuals, societies, and civilizations? A 
first point of contact lies in the logical-semiotic operations that are necessary to such a "rhetoric of beyond." Negating the present, encircling it by a fence, and imagining a way of communication between "here" and "beyond" is a common strategy of every narration, be it that which separates and at the same time unites two ontologies, or that which articulates an identity and its counterparts. The term "transcendence," indeed, does not originally belong to the lexicon of religions. In its Latin version, it is found rather in tales of military campaigns, of armies that must "transcend" an obstacle, usually a mountain chain, so as to reach, fight, and defeat the enemy. "Transcending" is, therefore, "going beyond," but also above and across the obstacle, toward a "beyond" that is imagined as other. It is only in theological-philosophical reflection that this topological expression becomes spiritual. It is therefore inevitable that the transcendent space becomes tinged with the colors of utopia: beyond the obstacle there will always be a fuller, superior, and more complete presence.

Seizing this first point in common is relevant as it leads to articulating a typology of "rhetorics of transcendence." Moreover, it leads also to understanding in what ways the sacred imaginaries (imaginaires) of transcendence influence the profane ones, that is, the myriad of "little tales of beyond" that stud our lives. This reflection suggests that also, nowadays mostly in lay contexts, the old tales of Transcendence continue to influence the way in which cultures posit, separate, and re-attain a "beyond." The success of conspiracy theories, for instance, which imagine a secret place in which noxious groups would imprison truth, is difficult to explain without surmising a "nostalgia of revelation," i.e., an ontological landscape in which truth is always beyond a curtain, unattainable without the aid of a messenger. In this case, then, transcendent felicity consists in the utopia of absolute transparency, attainable only through heroic revelations, and provided that the malign forces that defend the "wall of beyond" are defeated (Leone 2016a).

Tales of Transcendence, indeed also the "micro-stories of beyond," need an enemy, that is, a force that opposes the utopian ascent and crossing. If in Christianity it is the Devil who hinders the parousia, in secular variants of the salvific discourse this negative willingness can nestle everywhere, but often inherits the traits of the diabolical, thus betraying a further analogy between "secular" discourses and "sacred" ones. It is the oppressing Other, it is the frightening barbarian, it is "the different" at the door: all forces that loom large and work so that the tale of transcendence is reversed; not any longer an overflowing of the ontologically superior into the ontologically inferior, of perfection into imperfection, and of fullness into partiality, but rather, contrariwise, an overflowing of the basest, a spreading of the vile, and a brimming over of the vulgar. Positing transcen- 
dence means instituting an obstacle, but also "constructing an enemy," as Umberto Eco efficaciously titled one of his books (Eco 2011).

Indeed, there is no discourse of revolution that is not also a "tale of beyond," as well as a figuration of an obstacle, and of an adversary guarding it. So as to confirm it, suffice it to compare the rhetoric of this impulse with the inevitable political quietism of other metaphysics, those that preach a seamless coincidence between reality and perfection, a bending of the immanent over itself, and the illusory character of every effort. The ontological calm of the Far East does not escape the evolutionary centrality of negation, but channels it according to different rhetorics, keen on unmasking the thought of "beyond" (Rambelli 2013). Paradoxically, therefore, they aim at negating negation, at a "beyond" that coincides with the disappearing of any "beyond," in a vertiginous vortex in which perfection is reached by obliterating it. Nevertheless, this geography of the discourses of transcendence on the map of the planet is rather rough. Mystics, for instance-transversally to such banally geographic repartition-nourish the desire of extinguishing any desire, and re-appropriate the space of beyond through letting its profile collapse and adhere to the immanent word (Certeau 1982).

Tracing back quotidian transcendences to the imaginaries of Transcendence does not detect only discursive genealogies. On the one hand, a "beyond" and its set of boundaries and enemies are conceived of along the line of the metaphysical tale handed down by religions. Imagining a perfect humanity in revolutions is like imagining a paradise. On the other hand, at a superior and more rarefied level of abstraction, it can be argued that everyday transcendences are molded after Transcendence not only in their form, but also in their content. In other words, every "narration of beyond," and therefore ultimately every narration, is indebted not only to a semiotic logic that it inherits from the grand metaphysical narratives of the non-secular past; in addition, narrativity as a whole seems to stage a metaphysics, to express and at the same time reinsure the preoccupation that stems from the idea of a total, unreachable, and ultimately blind "beyond."

Greimassian semiotics repeats like a mantra that every tale wraps into discourse the struggle between life and death, nature and culture (Greimas $1970-83)$. As a matter of fact, it is merely through linking this semiotic hypothesis with a project of philosophy of meaning that such affirmation-at first sight insufferably abstract-becomes meaningful. Narrating is positing a "reachable beyond," and therefore taming - through symbols-the inextinguishable anxiety of a "definitive beyond." From this point of view, the grand religions of Transcendence and the countless tales of "quotidian beyond" do nothing but promise a "positive and possible beyond," which is ultimately communication. 
Rearticulating semiotics and communication studies as a "science of the beyond": that is, in a nutshell, the project presented here. But this project needs not only philosophizing, but also analyzing. That follows from a simple assumption: among academic disciplines, few have been able to articulate the relation between actual and potential, "here" and "beyond" in such a sophisticated way as semiotics, specifically in the study of enunciation (Manetti 2008). From the semiological point of view, indeed, "the beyond" is nothing but projection of an enunciating instance, débrayage, as Greimas would call it; and its re-approach is nothing but simulation of a return, embrayage. Semiotics studies such dialectics of detachment and contact-in a sort of breathing that reminds one, again, of the myths of Transcendence-more effectively than other disciplines, not by virtue of some innate epistemological superiority, but because it concentrates on language. It is indeed in language, and in the possibility of negation, that the idea of transcendence emerges. One need not marvel, then, that one of the subtlest disciplines of meaning and language is able to cast new light on the "fantasies of the beyond," on the ways in which transcendence is posited through signs.

\section{The linguistics of religious language}

The relation between language and religion can be investigated at several levels of abstraction (Leone 2016c). At the most concrete level, linguists can study the verbal language of a religious community (Keane 1997). Religious communities usually mark frontiers by adopting a verbal language that is different from those spoken on non-religious occasions (Darquennes and Vandenbussche 2011). Before the Second Vatican Council, for instance, the Catholic Mass showed linguistically marked frontiers (Yelle 2013: 158). Latin, a language that no living community spoke anymore with the exception of the Vatican itself, would then give expression to the Catholic ritual (Leonhardt 2013: 245-76). After the Council, the frontier was not as pronounced (Vincie 2013). However, different and subtler linguistic features started marking the frontier between the religious and the non-religious, the sacred and the profane (Lamb and Levering 2008: 101-46). Catholic priests would now speak vernacular languages, but still retain a distinctive prosody, which was absent in everyday language and displayed uniquely during Mass prayers, readings, and sermons (Crystal 1990). Linguists can study this prosody. They can analyze the way in which it alters the standard prosody and phonetics of a language (Holt 2006). In Italian, for instance, most priests produce a slightly nasal, distinctively high-pitched voice, prolong vowels, and introduce a singsong undertone in sentences (Lang 2012). They draw their 
words from the technical lexicon of the Catholic discourse, talking about salvez$z a$ (salvation), pentimento (repentance), peccato ( $\sin$ ), but mostly steering clear, at the same time, from the 'arid' idiom of theology (Coletti 2015). Sentences are usually arranged in paratactic structures, with frequent repetitions of words. In enunciation, references to the individuality of the priest are carefully avoided in order to systematically evoke the "us" of the community of prayer. Semantically, the struggle of the community against 'evil' is frequently chosen as the main narrative pattern. Yet the antagonist is seldom personified. The 'modern' Catholic priest rarely mentions the devil. Each of these layers (the phonetic, syntactic, pragmatic, and semantic layers) can become the object of rigorous linguistic measurement and analysis. Linguistics and its branches (phonology, syntax, pragmatics, semantics) are now perfectly equipped to conduct this kind of investigation. It would result in a precise idea of how the present-day Catholic community marks its religious space linguistically. Marginalization of Latin turned the Catholic Mass into a different kind of linguistic experience (Librandi 2012). Whereas before the Council many worshippers would not understand Latin (Beccaria 2001), now most believers immediately grasp the content of prayers, readings, and sermons (Johnson 2013). Continuity with everyday language, however, somehow mars the aura of ritual. It blurs its linguistic frontiers. Hence, other linguistic elements must be introduced, or preserved, in order to recreate that aura. The ultimate outcome of the analysis is an articulate, multi-layered map. It would show lines of continuity and discontinuity between a particular instance of Catholic ritual discourse and the surrounding sphere of linguistic varieties. On the one hand, the language of Mass marks its difference by referring to the discourse of the Church and its various internal articulations (homiletics, prayer, worship, specific sacramental formulae as they are taught and learned in Catholic seminaries). On the other hand, it connects with the profane sphere of language through non-marked features (adoption of local accents, sporadic references to the lexicon of contemporary media, in certain cases hybridization with other genres, such as political speech, etc.). Such a map would be indispensable to understand not only the Italian Catholic Mass as a linguistic phenomenon, but also as a religious, cultural, and social event. It would provide objective clues about the evolution of ritual in society. For instance, due to decreasing Italian vocations, many parish priests currently originate from Africa, Latin America, or the Philippines. They usually speak perfect Italian, but they carry distinctive accents. What is the semantic effect of this on local worshippers, who are mostly elderly and speak Italian dialects? On the one hand, it must be an experience of estrangement: a foreign accent suddenly replaces a local one in conveying the religious message to the community (Leone 2010a). On the other hand, this estrangement is not necessarily a negative one. It might contribute to recreate 
the lost aura of Latin. Furthermore, it might make believers feel part of a supranational community, thus encouraging a different perspective on the thorny issues of globalization (migration, distant wars, etc.). After all, since John Paul II, Italian Catholics have grown accustomed to, and even fond of, foreign accents in worshipping (Polish, German, now Argentinian).

\section{The semiotics of religious languages}

Following Saussure's original suggestion (Saussure 1972), the linguistic analysis of Catholic speech can become the model for a more encompassing study, taking into account not only verbal language, but also the many systems of signs that, collectively, weave together the phenomenology of the Catholic Mass (Leone 2014a). The Second Vatican Council had an impact on all of them. It radically changed the verbal language of the Mass, but it also affected other expressive codes. The priest started facing the faithful, and the new posture entailed alterations in other sign systems too (Lang 2004). The architecture of the church adapted to the new ritual choreography (Schloeder 1998). Materials changed too, and their codes of signification with them (Leone 2016). For centuries, the Catholic Church had marked its ritual space through the display of silver, gold, and gems, arranged in exquisite forms (Leone 2014c). The best-and most expensive-artists were contracted in order to design churches, decorate them, and fill them with lavish representations of transcendence and its emissaries (Lukken and Searle 1993). Some religious movements within the Church, such as the Franciscans, questioned the equivalence between material and metaphysical splendor. However, their 'poor' materials (the rock pillow of Saint Francis, his wooden cross) would signify a different religious and existential style only by contrast with the mainstream material glory of the Church. Gold was to the material semiotics of the Church what Latin was to its linguistics. It marked the frontier of a ritual space (Waquet 1998). It created an aura. Similarly, as the Second Vatican Council introduced vernacular, profane languages into the temple, so it simultaneously stripped it of its golden attire and filled it with plastic, the quintessential material of profane modernity. Linguistics is neither meant nor equipped to study this range of non-verbal changes. Semiotics is. Structural semiotics takes the lead from structural linguistics. It adopts its theoretical and conceptual framework. It embraces the structural notions of difference, value, paradigmatic and syntagmatic axes, langue and parole (in Hjelmslev, "system" and "process"), signifier and signified (in Hjelmslev, "expression" and "content”), matter, substance, form, etc. At the same time, semiotics must develop this framework into a specific toolbox, as has been largely done by semiologists 
and semioticians from Barthes on. However, given the intrinsically multifarious character of the semiotic object, development must continue and adapt to specific systems of signs. As regards materials, for instance, Hjelmslev's (1943) model of the sign is a good point of departure. Signs involve a dialectics between two planes, expression and content, but also among three "strata" within each of the planes: "matter," "form," and "substance." The expressive code of pre-Second Vatican Council craft would select a specific matter, namely gold, and turn it into a symbolical material through reference to a widespread cultural form. According to such form, gold is unsurpassed in conveying the values of preciousness, exclusivity, eternity, distinction, etc. (Venable 2011). Post-Second Vatican Council churches have kept many of the previous furnishings. Global modernity, however, has leached into the ritual not as much through objects as through their material. Already in 1884, the French writer Joris Karl Huysmans, in a famous passage of $\grave{A}$ Rebours (translated into English as "Against Nature" or "Against the Grain") would sarcastically criticize the adoption of 'poor' materials in the Catholic ritual par excellence, the Eucharist (Huysmans 1884). Was transubstantiation really taking place, now that priests were not using wheat bread anymore, but all sort of surrogates, such as "dreadful" potatoflour bread (Caspers, Lukken and Rouwhorst 1995)? Semiotics, unlike linguistics, is meant and equipped to deal with the meaning of materiality not only impressionistically, like writers usually do, but also scientifically (Van Tongeren and Caspers 1994). Gold, for instance, can be decomposed in its structural features of color (saturation, luminosity, hue), texture, luminescence, and resilience (Floch 1984). Each of these features is attached to a specific range of symbolic connotations, embedded in a series of genres and discourses. Structural analysis pinpoints the semantic effects of material replacement. Wood eliminates the luminescence and texture of gold, but to a certain extent maintains its resilience. Plastic, on the contrary, completely subverts the "material discourse" of gold, and such subversion inevitably "contaminates" the furnishings of worship (Boscagli 2014). In a plastic crucifix, inorganic texture, opacity, and extreme malleability of the material reverberate on the semantics of the ritual object. The faithful can transcend materiality, and believe that matter does not actually matter. Nevertheless, such disregard for the material will require meta-semiotic instruction, which the Church must provide, if it wants to dispel misinterpretation (a wooden crucifix is a sign of the "Church of the poor" at least since Saint Francis; a plastic crucifix, on the contrary, can be interpreted as sign of "disposable religion") (Sandino 2004). 


\section{The philosophy of religious signification}

Linguistics and above all semiotics can also investigate religion at more abstract levels (Leone 2012c). The analysis of how verbal language and other systems of signs behave in religious settings is certainly useful. Along this line, both linguistics and semiotics provide more consolidated disciplines of religion-such as history or anthropology of religion-with new and powerful analytical frameworks (Yelle 2013). However, limiting the function and purpose of semiotics at this level of the relation between language and religion would be overly restrictive. Semiotics can be ancillary to the history and anthropology of religion, but can also explore more abstract levels of investigation. Such operation fundamentally consists in the construction of a meta-level or, in other words, in a sort of convolution (Leone 2013b). Structural linguistics and semiotics produce insights about language and religion by applying their theoretical and analytical frameworks to particular instances of religious language or, more broadly, of religious signification. Such analysis, however, cannot exclude a self-reflection on the fundaments of the structural paradigm itself. For instance, why should meaning derive from structures? And why should structures stem from differences? What defines the ontology of difference, and how does this ontology produce value? What is cognitive, and what is cultural in the human construction of meaning? Is that a unique phenomenon in nature or can it be found in non-human cognitions as well? At less abstract levels: why do most cultures organize meaning through oppositional schemes, and what is the relation between this structural scaffolding and the emergence of narration? Why do most cultures need to circulate values and meaning through stories (Leone 2015)?

All of these theoretical questions concern religion: what is the ontological structure of meaningfulness in a religious tradition, and how does it transmogrify into metaphysical topology, ritual architecture, and a tradition of narratives? Do religions always conceive of meaning antagonistically, as the structural paradigm suggests, or is the structural paradigm itself deeply and covertly influenced by "Manichean" religious ideologies? Are there religions that, conversely, think of meaning as a continuum, without oppositions or superposition of dialectic planes (signifier/signified; system/process; etc.)? At this level of abstraction, short-circuit is almost inevitable: am I thinking of religion in semiotic terms, or am I thinking of semiotics in religious terms? The analyst must be able to question the fundaments of the structural paradigm not only in semiotic terms, but also in religious terms in order to turn this vicious circle into a virtuous spiral. Here "religion" should be meant in a very abstract way as well. This shift of paradigm would indeed entail the following self-interrogation: is there 
something sacred at the roots of meaning? Or, to say it in a less mystical way: is what founds the ontology of structuralism (difference, value, structure itself) posited in a way that reminds one of the foundations of the sacred (à la Durkheim)? Most analysts would not accept this turn. Semiotics is a secular discipline. It stems from a scientific project. It is not ontology. It is even less metaphysics or theology. To most if not to all semioticians, the suggestion that the postulates of the discipline might share ontological presuppositions with religious thought would sound threatening.

\section{The religious philosophy of semiotics}

The point here is not to "convert" semiotics. Neither is it to investigate the deep influence of religious thought on the founders of the discipline (starting from Peirce) (Robinson 2010). The point is, rather, to indicate that the relation between religion and language can be investigated also at a more abstract level of ambition. At this level, the linguistics of religious language, as well as the semiotics of religious signification, must yield to a philosophy of religious language. What is the purpose of such a branch of philosophy? Mainly, to speculate about religious presuppositions implicit in the linguistic and semiotic understanding of meaning; to explore the origins of the "ideologies of meaning" and to place such origins in relation to the religious dimension. Is the human understanding of meaning hardwired in the physiology of human cognition? Or is it a cultural construct? And in either case, what is the relation between this "cognitive hardware"/ "cultural software" and the emergence of religious thought? Such are the typical questions that a philosophy of religious language must investigate (Leone 2012d). Different paradigms can be adopted in order to carry on speculation: analytical philosophy, cognitive linguistics, semiotics, etc. Whatever the paradigm adopted, though, the result is doomed to be highly disappointing for those who would like to attain the same level of clarity that analytical semiotics usually displays. For example, it is one thing to adopt semiotics in order to understand the symbolic connotations of vernacular languages in Catholic Mass; and quite another to develop a meta-reflection on how the Christian ideology of religious meaning influences the "Western" conception of language (Keane 2007). The latter endeavor is destined to be much more speculative and tentative than the former. It is also destined to be more adventurous. Indeed, the ultimate question of the philosophy of religious language turns this discipline into a religious philosophy of language: what is sacred in language? And what is semiotic in the sacred? 
The following sections will seek to approach these questions within the semiotic paradigm. Before proceeding, though, it should be pointed out that the highly speculative nature of the endeavor does not exclude its momentous sociocultural consequences. One of them is a radical rethinking of "secularization." Are we secular simply by expelling references to religious traditions from our language and systems of signs? Or is there a much deeper level at which the social scaffolding of meaning keeps being impregnated by religious ideologies?

\section{Mystical semiotics}

What follows must remain not only highly speculative, but also evocative. Semiotics, especially in the tradition of Saussure / Hjelmslev / Greimas, seeks to avoid any contamination with the semantics of the language-object by creating an aseptic meta-language (Greimas 1966). Structural and above all generative semiotics pursue the utopia of a neat distinction between the analysis and the object. Hence, they cultivate the myth of a rigorous inter-definition of terms, whose ultimate editorial product is the dictionary: in Greimas's Dictionnaire, the key terms of the semiotic meta-language are defined and inter-defined once and for all (Greimas and Courtés 1979). Being a sophisticated lexicographer, Greimas himself certainly knew that this effort of definition could not be exhaustive. First, the theory evolved. Publishing a second dictionary became necessary a few years later (Greimas and Courtés 1986). Second, no meta-language, not even that of mathematics, is immune from contaminations from the languageobject. To prove this, it is sufficient to realize how difficult it is to translate Greimas's dictionary into other languages, and especially into non-Romance languages (Leone 2016b). Nevertheless, at the level of semiotic analysis, the meta-language of semiotics must be precise and inter-subjective. It must aim at the opening of a meta-linguistic arena for discussion about meaning among specialists. Such an operation is essential for linguists who inquire about religious language, as well as for semioticians who investigate religious signification (Leone 2017). Despite the inevitable pressure from one's socio-cultural (linguistic, religious) background, the analyst must strive for objectivity, or at least for inter-subjectivity (Leone 2012b).

However, if the meta-language of semiotics itself is placed under scrutiny so as to explore its religious or, more deeply, its sacral presuppositions, then what should this meta-meta-language look like? On the one hand, this exercise at religious philosophy of language should not give up sharing a space of inter-subjectivity. After all, even theology has its inter-defined dictionary. On the other hand, such an arena cannot be shaped and furnished in the same manner as 
is usual in structural and generative semiotics. Delving into the depth of abstraction, searching not simply for meaning, and not merely for the meaning of meaning, but for the origin itself of meaning, the analyst must become a philosopher and, to a certain extent, a mystical poet. But is a mystical semiotics really viable? Does it not perhaps run the risk of losing the communicability and, ultimately, the credibility of academic rhetoric? An effort of equilibrium, or even acrobatics, is in order. Mystical discourse is often acrobatic (Petit 1997). It balances on the abyss of meaning without ever falling. Similarly, the meta-semiotics of religious meaning must strive for communication while yielding to the lures of abstraction. Examples of this kind of acrobatics are not uncommon in the human production of meta-levels of meaning. Arguably, most contemporary arts concentrate on such production. Malevich's Suprematist painting, for instance, aims not only at developing a pictorial reflection on reality, like that proposed by Western art at least since Giotto onward. More ambitiously, and more convolutedly, Malevich's painting seeks to deliver a pictorial reflection on painting; on the essence of Western painting, and above all on its presuppositions (Malevich 1999). In order to attain such a goal, Malevich does not give up visual communication. His black square still appears to the viewer like a recognizable form, with an identifiable color and a graspable position on the canvas (Shatskikh 2012). The viewer can still talk about the meaning of this image and seek to translate it into words (Figure 1). However, visual communication is pushed into the background by the needs of meta-pictorial reflection. What matters indeed is not to signify the shape, color, and topology of a black square, but to invite the viewer to delve into this obscure bi-dimensional tunnel, into this meta-pictorial black hole. The operation is risky: what one will find in the meta-pictorial arena opened by Malevich is not to be predetermined. Yet the solution is not to close the square, and to return to Giotto. On the one hand, such return to visual innocence would be impossible. On the other hand, the correct way to respond to Malevich's challenge is not unbridled mystical drift, but meta-semiotic sophistication. What does the black square reveal about the origins of the idea itself of painting?

What follows is, therefore, a meta-semiotic exercise à la manière de Malevich, a Suprematist perspective on religious signification. There are no entirely safe bridges to be used to keep from falling into the chasms of entirely subjective meaning, yet elaborating on the existent meta-language of semiotics will anchor this Suprematist effort to the inter-subjectively consolidated framework and lexicon of the discipline. 


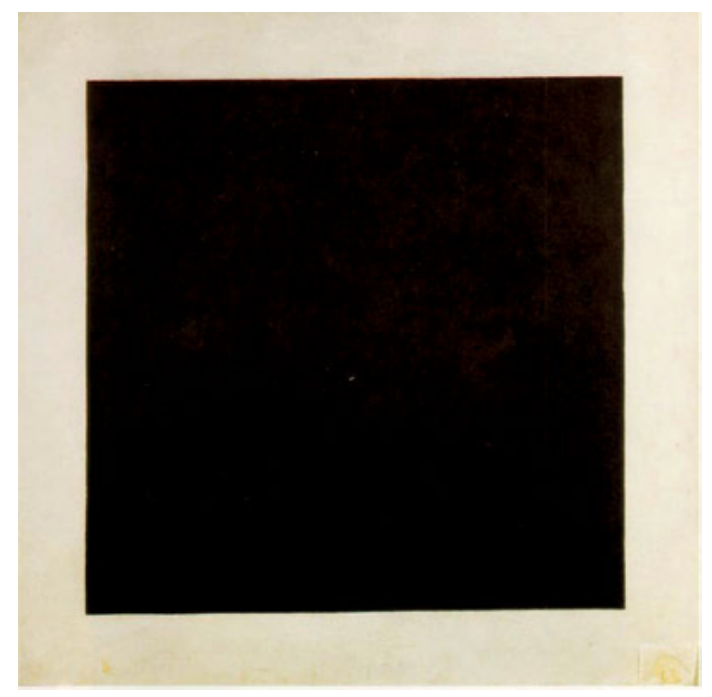

Figure 1: Kazimir Severinovich Malevich (Russian: Казими́р Севери́нович Мале́вич), Black Square, ca. 1923. Oil on canvas. 53.5 x 53.5 cm. St. Petersburg, Russia, State Russian Museum.

\section{Intransigence}

The first step proposed here is to tentatively establish $a$ semiotics of the obstacle. As it was suggested earlier, it is impossible to posit transcendence without situating, as its counterpart, a limit, a barrier, and a negation separating it from immanence. Any thought of alternative potentiality stems from the possibility and installation of such frontier. Negation works, in its topology, like a more or less impenetrable veil, standing between a mental state and its apperception, between the description of this state in language and the idea of a presence. Negating is constructing a barrier around meaning (Leone 2011a). It is for such reason that semiotics must study the human modalities of separation. Before meaningstructural and general semiotics are aware of this-there is difference, but this difference is impossible without the idea of an alternative that originates from separation, from delimitation (Leone 2011b). The tales of Transcendence-as well as the micro-stories of quotidian transcendences-posit a tension between these two polarities of meaning; they also establish an axiology. What is an axiology, indeed, if not a slope of meaning? Given a dichotomy posited by a limit, axiology imposes the drifting of a side towards the other, according to dynamics 
and channels that are each time determined from the discourses and rhetorics of transcendence. Axiology is a wind.

In Judaism, for instance, the prophets, and above all Moses, from time to time ascend up to God, and yet this ascent, and the contact with Transcendence that follows, are always difficult, full of obstacles, and sometimes deadly. Normally, indeed, the slope of the Jewish discourse of Transcendence entails downwards openings, communication channels that only God decides to open and close (Volli 2016). In Christianity, Incarnation is also descent, so much so that myriads of pictorial Annunciations represent its metaphysical beginning like a Holy Spirit/Dove swooping down toward the womb of the Virgin Mary (Arasse 1999). However, embodied transcendence inevitably becomes an immediate and quotidian access-gate to divinity, a numen that all can touch, to whom all can speak, and that-utmost scandal-all can also reject, persecute, and crucify.

As has been underlined earlier, the obstacles with which the present section on "Intransigence" deals are not metaphysical but semiotic. They are frontiers, boundaries, limits, and demarcations that communities posit in order to defend their interpretive habits from the dreaded siege, and the possible assault, of external forces that might upset their delicate equilibriums. They are physical instances of intransigence, which block the circulation of people and objects, but they are, above all, textual instances of intransigence, which construct the morphology of a semiosphere exactly as they determine its thresholds of porosity and impermeability (Lotman 2004). Every intransigence, however, calls for transcendence, that is, the idea of axiological tension toward a "beyond" in which the obstacle is removed, the boundary destroyed, and the partial equilibrium of a community becomes total, quiet, and undisturbed by internal or external perturbations.

One of the most important purposes of articulating a semiotics of intransigence is showing that discourses of transcendence are not all the same. Some, on the one hand, invoke utopian potentiality in order to exclude, subjugate, and discriminate. That is the case of the supremacist fantasies linked with the idea of perfect nation, community, or state. Transcendence in this case consists in a world without beyond, without alternatives, but above all in a world without the Other, without those who-because of their ethnicity, religion, sexual orientation, etc.-perturb the dream of absolute social parousia. On the other hand, at the other extremity of this polarization, discourses of transcendence can invoke not the elimination of the Other beyond the frontier, but the elimination of the frontier itself on this side of the Other. It is the case of those religious or revolutionary discourses that invoke the idea of a perfect alternative of the real in order to eliminate its articulations: there is no black and white, man and woman, rich and poor, but human beings who, artificially divided, are intrinsically destined 
to a common "beyond," be it that of abolition of property or the pleroma of revealed religions (West 2004).

The most delicate aspect of an examination of intransigence consists in contemplating that these two categories of discourses, apparently antipodal, might in fact be intertwined. Every rhetoric that posits an obstacle, outlines an intransigence, and, in thus doing, sketches the project of its transcendence-toward an ideal state without tensions-is in reality a rhetoric of overcoming, in the sense that it does not consider difference as intrinsic, but as a problem. Granted: enfranchising oneself from differences imposed at birth by nature so as to establish a common project of shared living, outlined by culture, appears as preferable to the project of annihilating every minority. But are they so neatly distinguishable? Is the Christian idea of universal evangelization so distant from the idea of an empire that stretches limitlessly, without any periphery? In other words, doesn't the instinct that leads one to institute a narration of the obstacle, inevitably ending up in its overcoming, result from a specific ideology of transcendence? The comparison with other cultures shows that that is maybe a universal feature, which is nevertheless inflected in different ways depending on the (especially religious) discursive spheres of reference. In some rhetorics of the Far East, for instance, the obstacle is not implicit invitation to its overcoming-be it through a foray of immanence into the transcendent (Revolution), or an overflowing of the transcendent toward immanence (Revelation), but is, instead, a paradoxical hint to its own illusory character: it is useless to throw oneself beyond the obstacle, because beyond the obstacle there is nothing (Jullien 1996).

The challenge of a semiotic point of view on the discourses of intransigence consists in the project of their characterization in formal terms. From the semiotic perspective, as it has already been indicated, construction of a "beyond" coincides with enunciation. It is only in enunciation, indeed, that discourse can posit, at the same time, the idea of the potential co-presence of all alternatives-within an abstract instance preceding enunciation-and the idea of their selection, entailing the expulsion of a "beyond" and the implicit construction of a boundary between the center of discourse and its simulacra, between the abstract origin of language and its utterances. That means that elaborating a semiotic typology of intransigence is tantamount to studying the semiotics of this passage, that is, the discursive forces and forms through which a spatial, temporal, and subjective difference, and above all a difference of values and ideologies, are established between a hypothetical center and a "beyond," between a supposed full kernel of presence and a topology of yet absent potentialities; still absent for they are concealed by the figural obstacle of language, and yet always reachable through the mystical or revolutionary élan, through revela- 
tion or incarnation, or by means of all the operations that, at the same time, both outline and overcome the boundaries of "beyond."

\section{Transparency}

One of the most pragmatically effective ways of evoking transcendence is to veil it (Leone 2014c). That happens undoubtedly in the so-called revealed religions, in which specific references to the device of the veil, its usages, and its metaphors abound (Leone 2015: 121-196). In all the Abrahamic religions, sacred texts, exegeses, liturgies, not to mention tales, hagiographies, and iconographies, offer numerous examples of veils. The veil is, moreover, a transcultural device: it occurs as an element of Western as well as of Eastern metaphysics. Indeed, if revelation is, literally, in the aid of a transcendence that accepts a partial withdrawal from its mystery, such religious metaphor has its origin in the quotidian veiling that continuously courts perception. Proposing one's body to society, preparing it for culture, and inserting it in a circuit of communication means, in most cultures, encircling it with a more or less thick veil (Leone 2010b). Yet, as in spiritual Revelations, so in the everyday ones, the veil does not simply function as a tool of occultation. It hides, of course, but always according to patterns and modalities that never completely eliminate transparency.

The present section therefore designates by "transparency" the seductive attitude of transcendence. Positing transcendence, it has been repeated numerous times, is tantamount to situating both an obstacle and a potentiality beyond it. Tension between actual and virtual, present and absent, imperfect reality and complete ideality, however, cannot be triggered-thus becoming both tale and passage, myth and action-if such obstacle does not function somehow exactly like a veil. The obstacle indeed delimits a "beyond," situates it as alternative to the ontology of immanence, and yet simultaneously winks, suggests, and invites. There is no transcendence, not even in the most austerely iconoclastic religions, that is imagined as totally torn from any relation, coldly solitary in its total impenetrability. On the contrary, as humans think of a "beyond" through negating actuality, they imagine not only channels, bridges, and passages, but they connote also the boundary between "here" and "beyond" as an allusive frontier, as a veil that hides and at the same time lets one catch a glimpse of forms, movements, and light. Transparency is, therefore, the perceptual anticipation of transcendence, the filtering of "beyond" in "here" through modalities that, again, semiotics is called to investigate and classify.

Semiotics offers concepts and theories capable of formalizing all these processes of transparency, these dynamics of revelation and re-veiling. In Greimassi- 
an semiotics, for instance, the dialectics between the obstacle as agent of occultation and the obstacle as sign of a "beyond" can be grasped thanks to the notion of observer-actant, that is, the narrative function that texts deploy so as to suggest a specific prospective on the circulation of meaning in narration (Fontanille 1989). The discourses of transcendence, as well as all the "narratives of beyond," on the one hand construct an observer-actant that is modalized according to (lack of) power: when one is on this side of the obstacle, one is immersed in shadow, obscurity, and ignorance. From this point of view, the obstacle (the wall, the veil, the frontier) functions as an opponent-actant, which prevents the axiological glide of narration. On the other hand, though-sometimes in a very paradoxical way-the obstacle functions also as sender-actant, meaning that it modalizes "the eye of narration" according to the desire of looking, experiencing, and knowing. That is exactly how every veiling works: as attribution of scopic impotence, and at the same time as incitement of perceptual agency.

In "transparencies of beyond," meaning can be glimpsed on the other side of a veil that simultaneously conceals and suggests it. Rhetorics of transparency nuance light and shadow, opacity and diaphanousness in order to keep the perceptual tension with "beyond" alive. In the semiotic study of religion, such rhetorics must be the object of punctual examination.

\section{Transit}

Transits are opposed to the intransigencies described in the previous section. There is, however, a conceptual difference between transits and transcendences. As has been said, transcendence is the result of a linguistic instinct, perhaps a universal one, that is capable of both negating what exists and linking it-beyond an obstacle-with a virtual elsewhere, with a potentiality often imagined as a preferable set of values. Axiology stems from this preferability, and narration from this axiology; here narration is meant as the series of variously arranged channels that allow the "axiological wind" to blow. Transits do not coincide with transcendence, but are, instead, experiences of beyond. There is transit every time that an intentionality, and therefore the agency stemming from it, detach themselves from the plexus of "I/here/now" so as to imagine, or to attempt, a re-appropriation of "beyond."

Such intentionality leads to several results, some of which are paradoxical. Transiting across a frontier does not destroy it but confirms it, also in the case in which the ultimate goal of transiting is utopian union with transcendent potentiality. The Christian thought of Resurrection, for instance, does not eliminate the idea of death. It promises its overcoming, which it depicts in countless icono- 
graphic forms. But in such promise it paradoxically reinforces the thought of an ultimate and insurmountable barrier, which is surmountable only thanks to divine aid. Christianity does not abolish death but it transports one beyond it. Likewise, in quotidian transits-those of social practices that challenge political frontiers, for instance-transits are not revolutions but, paradoxically, operations that reaffirm a limit.

Semiotics must map this mechanism, which is essential in the functioning of semiospheres. As it was underlined earlier, they owe their morphology to a series of more or less intertwined intransigencies. Establishing the ubi consistam of a community of meaning is tantamount to determining its idealities, that is, the map of negations that outline the virtual limits within which members of such a community semiotically operate. Lotman taught us that adhering to a culture inexorably means positing a "beyond" imagined as more or less threatening and, in any case, never semiotically inert (Lotman 1973). The frontier of the semiosphere implies that the topological space beyond it is an object of either assault (the project of transcendence consists in unlimited and total expansion of the semiosphere, like in Christianity), or defense (the project consists in avoiding an opposite axiological overflowing such as, for instance, the expansion of polytheism over a monotheist minority in certain phases of Jewish history). More generally, each time that the rhetorics of transcendence are at work, they produce transits, i.e., semiotic operations that open new channels of communication across the frontier, thus paradoxically contributing to determine it as dialectics of porosity and impermeability, intransigencies and passages.

Again, then, a task of the semiotics of religion is to elaborate a typology of such operations, which eventually comes down to a classification of embrayages, i.e., discursive mechanisms that, in different languages, construct bridges between this side and that side of the semiosphere. Challenging the ineffable character of transcendence through mystical poetry or designing images meant as gates between immanence and transcendence (Leone 2014b) are nothing but different manifestations of a common rhetoric of transit, attempts of re-appropriation that, oxymoronically, at the same time challenge and confirm the intransigencies of meaning.

\section{Transaction}

Semiotics should also explore the fractal character of discourses that posit, narrate, and communicate transcendence. If every transcendence-both the "macroscopic" ones of revealed religions and the "microscopic" ones of the daily exercise of human imagination-originate from negation of the existent, and from 
the consequent projection of an "elsewhere" beyond that negation, then "transitivity" here designates all processes that, in immanence itself, reproduce such dialectics of occultation and revelation, in a sort of infinite mise en abyme. As has been underlined earlier, religious and spiritual ideologies of transcendence influence all the imaginaries of the "elsewhere," including the "secular" ones. Underlying both is the same anthropological instinct, that of potentiality; yet, it is in religious cultures that such instinct gives rise to specific and, above all, communitarian habits. In religions, and not only in the revealed ones, the human access to potentiality does not remain mere rêverie but becomes a system of habits that codifies the nature of transcendence and its relation with the immanent in sacred texts, liturgical practices, and even exceptions. The millenarian crystallization of such habits marks a great part of human history. In relation to this very long period, the so-called "secularization" is nothing but a recent, fleeting appendix. Hence, it is reasonable to think that every imagination of beyond deep-down follows models that, albeit abstractedly and subconsciously, refer to religious narratives of transcendence.

Yet, semiotics must not be content with recording the impact of religious imaginaries of transcendence on quotidian "narrations of beyond." On the contrary, it takes these for granted. It inquires, instead, about a sort of matrioska-effect, wherein the fact itself of positing transcendence leads, by transitivity, to structure an analogous hierarchy of levels within the immanent dimension itself. Overall, studies in this domain must do nothing but return, each from a particular perspective, to the same mechanism, which essentially is the mechanism of interpretation. They must suggest, namely, that where there is interpretationeven where apparently no reference is made to transcendence or to "beyond"-interpretive intentionality itself installs a sort of veil, leads to a splitting of levels, or even to their multiplication. For the interpreter, reality is never itself, but always also something else. The signifier functions exactly like a veil, which hinders the full deployment of meaning and, simultaneously, appears as the only way to approach it. Nevertheless, such nearing-exactly like in narratives of Transcendence-is never definitive but constantly asymptotic, proceeding through cumulative and progressive displacements of the obstacle, by little steps into the "domain of elsewhere." Fractal transitivity is therefore that which institutes a "beyond" in every reading, almost assuming that there is always-somewhere and somehow-a beyond of the text, a greater fullness to be grasped through a more or less rigorous method, through dismembering the textual carapace. 


\section{Transcodification}

No God is an island. Isolated transcendence does not exist. In no religious culture is transcendence situated totally beyond the reach of human beings. If projecting superior potentiality means taming the idea of finitude by means of an innate capacity of negating and imagining, then this projection cannot ever be self-centered, and result in the fantasy of "absolute beyond," for "elsewhere" is thus posited exactly in the hope of redeeming the existent. Nevertheless, transcendence is not born with language. As has been underlined earlier, it originates, instead, from entrenchment, from the outlining of intransigence. It is the obstacle that brings about "beyond," as it is negation that creates potentiality. Yet as soon as the obstacle is conceived as such, it begins to function like a veil, which -as it was pointed out in the section on "transparencies"-simultaneously hides and seduces. In this play of occultation and partial ostentation there lies already the first embryo of transcendence that is not absolute anymore but in communication with immanence. Crossing the frontier of "beyond" (transits), assaulting the ideal (transactions), or also imagining its simulacrum in the immanent (transitivities) are all steps in the progressive construction of a system of habits, that is, the opening of socially shared channels that allow transcendence to present itself no more only as ferocious alternative but as project.

There is something paradoxical in this movement that posits a beyond only in order to subsequently re-appropriate it, but it appears as paradoxical only if the pre-modern conception of narrative is forgotten in order to blindly embrace that of modernity. The narrative of consumption is a tale in which what matters is the opening toward a potentially infinite new. It is, indeed, the illusion of this never-ending self-reproducing novelty that triggers desire and, therefore, transfer of value, as well as transfer of life. The global system of entertainment rests on such foundations: all is conceived in order to conceal repetition and transmit the illusion of continuous renovation. That too is a way of contrasting the idea of finitude, but it is perhaps less efficacious than that inscribed in pre-modern narrations. Here, it is not the meaning of the new to be continuously re-proposed, but pure and simple repetition (Leone 2011b). One already knows how the tale will end, and yet one follows it, for what matters is not to discover the epilogue, but to lull oneself in the circularity established between beginning and end, between transcendence that emerges with a sender and its definitive annexation after the vicissitudes of narration. The modern tale is not ritual. The true ritual of modernity is consumption. But that is why modernity leaves so many unsatisfied; because it is a ritual that constantly needs fresh energies, like a vampire. The ritual tale of pre-modernity, instead, is self-sufficient. It does not need to consume new 
symbolical resources, nor does it generate consumption or profit, for it rests on a liturgical pact: everything will take place according to prescriptions, because what matters is not the epilogue but the tale itself, its circularity.

Transcodifications, then, are attempts at establishing such circularity; they are proposals of a pact with transcendence-the beginning of the crystallization of the "word of beyond." Neither habit yet, nor language, corresponds, in Peirce's semiotics, to the first emergence of thirdness. ${ }^{1}$ Firstness does not exist if not in abstraction. In the structural semiotics of enunciation, it corresponds to the reconstruction (or the postulation) of an instance in which diversity still holds as co-presence. The positing of an obstacle already brings about secondness: the existent is not blind any longer, but conceives of itself as relation to another, in the dialectics of seeing and not seeing that the obstacle-like a veil-establishes. From this point of view, intransigencies are not yet relation but its beginning or provocation. Transparencies, transits, on up to transactions are all phenomenologies of the passage from secondness to thirdness. They seek to found a relation, a channel, and a rituality that might bestow meaningfulness to "here" through its dialogue with "elsewhere." Transcodifications turn such attempts into the embryo of a language. As it will be seen, indeed, a transcodification of the transcendent can prove efficacious, contagious, and therefore become code, that is, language and ritual together. ${ }^{2}$

Two questions arise in this regard. The first: is there a grammar of transcendence, which determines the establishment and above all the consolidation of certain channels instead of others? What is the role of history when it exerts pressure on some discourses of transcendence and makes them turn into increasingly shared habits? Moreover, what specific forces and agencies are subsumed in the word 'history'? It is undoubted that selection-not natural selection but a cultural one-of transcodifications of ideality exists, but to what processes does it respond? The question is immediately relevant as regards the history of the languages of "macroscopic" Transcendence, for instance, the progressive marginalization of certain texts, liturgies, and transcodifications reputed as unable to provide effective and satisfactory access to ideality. But how does a ritual die? And how does it lose competition with alternative rites? Moreover, in the do-

1 In the framework of a phenomenology of religious meaning, the emergence of thirdness coincides with the first establishment of inter-subjective patterns of relation to transcendence, which will be subsequently codified into a Law.

2 In Peirce, First-, Second-, and Thirdness are variously defined but generally refer to a theoretical reconstitution of the phenomenology of meaning, in which an object cannot signify as such (First), but only in relation to a representamen (Second), mediated and turned into interpretive habit by an interpretant (Third). See Volkhard Krech's chapter in this volume. 
main of "microscopic" transcendences: what are the codes of "beyond" that a society discards as inadequate, and for what reasons? Studying the transcodifications of both Transcendence and transcendences means conceiving the whole project of human communication as an attempt at self-communication (Lotman 1990). That has to be explored not only in relation to explicitly religious discourses, but also in common rhetorics of potentiality, those that continuously design distant idealities so as to subsequently invent the project of their re-annexation.

Second question: what is the flavor of successful transcodification, one that manages to establish a channel inter-subjectively shared by a community of believers, not only in the religious domain but also in any other area of the semiosphere? It is the sweet taste of the appeasing of all tension, or it is rather the bitter taste of a tale that, as it becomes myth, ceases to involve its believers and turns into routine, drowsiness, new district of the existent, of what is not potential any more but, trivially, actual? In other words: isn't perhaps tamed ideality a grotesque expansion of the immanent, of its laws, and of its platitudes?

\section{Tradition}

Tradition is not simply transportation. Etymologically, it is the passage of an object beyond a frontier. It implies, therefore, the idea of value that is both constructed and defended in the passage. Going beyond the obstacle entails, indeed, struggle, labor; what is transported beyond is, as a consequence, essential. In relation to transcendence, as it has been defined in this essay, tradition consists in friendship, that is, in solidarity. It is both horizontal and vertical solidarity. Horizontal: one does not establish a tradition on one's own. One does not invent a language on one's own. Communication with transcendence, also in the case of the "macroscopic" ones of the ascetic or of the individual believer, is established as inter-subjective habit. The necessity of this communitarian aspect of tradition derives from its vertical purpose: transmitting beyond the obstacle means deciding what, in a semiosphere, is worthy to become culture; to survive. There is something syntactically paradoxical in such survival. On the one hand, one could think that languages of ideality compete and decimate each other like species, until the fittest occupies the kernel of the semiosphere. Nevertheless, history does not exert on signs the same pressure that nature exerts on genes, because history itself is a conglomerate of signs. The syntactic and non-semantic paradoxical character of tradition consists in the fact that it essentially is self-communication: one transports "beyond" that which is worthy, but that which is worthy is exactly what is transported beyond. There is no reason for which a cer- 
tain rite challenges the unfolding of centuries. A rite is sacred insofar as it permits continuous renewal of the existent toward ideality.

The dialectic put forward by the present essay is therefore not a Hegelian one. There is, on the contrary, a frictionless fluidity in the process that posits an obstacle, lets a beyond shine through it, crosses its frontier, conquers its space, imitates its forms, probes its language, until it establishes with it a golden bridge. All that is part of a single game, in which the abyss is created only in order to subsequently build this bridge. It is not clear whether this self-communication responds to a motivation or it is only the fruit of an anthropological cognitive mechanism out of control. Determining it is not so important. What is important, instead, is grasping the way in which many human cultures, if not all of them, resist the idea of their finitude, of their confinement within an ineluctably limited body. Positing transcendence means imagining a "beyond" of this limit, but is only in a tradition that transcendence opens up to reality.

Tradition, however, is not the end of history. Considering tradition as the arrival point of exchange with transcendence is a conservative stand only if it is interpreted in a banally political way. From the semiotic point of view, instead, tradition implies extraordinary effort of control over reality, which essentially translates into a series of codifications. What is a code, indeed, if not the attempt at caging matter? And what is tradition if not a successful and consolidated transcodification, which keeps the accidents of reality under control so as to trace the channels of communication with transcendence? A liturgy as well as a political manifesto outline a path toward ideality, and yet they necessarily must come to terms with the dust of history, all the more as they do not uniquely consist in an arrangement of words but in gestures, acts, and even revolutions. Therefore, there is a traditio facilis, which is that which codifies communication with transcendence into rigid, almost inflexible systems of signs. That is the case with sacred texts, carefully copied, learned by heart, and defended by sword. But there is also a traditio difficilis, which seeks to codify not the text but the body, or even imagination. If the former is subject to errors and flaws, the latter is the place where tradition yields to treason, the way becomes deviation, and transcodification more often gives rise to unavailing experiments than to traditions. It is the body that ultimately resists tradition, but perhaps it is exactly this resistance that nourishes the word of transcendence. One cannot dream of a perfect language without having an untamable body. The imperfection of the body yields to the dream of a perfect word. Caro verbum factum est. 


\section{References}

Arasse, Daniel. 1999. L'Annonciation italienne: Une histoire de perspective. Paris: Hazan.

Beccaria, Gian Luigi. 2001. Sicuterat. Il latino di chi non lo sa: Bibbia e liturgia nell'italiano e nei dialetti (1999). Milan: Garzanti.

Boscagli, Maurizia. 2014. Stuff Theory: Everyday Objects, Radical Materialism. New York: Bloomsbury.

Caspers, Charles, Gerard Lukken, and Gerard Rouwhorst (eds.). 1995. Bread of Heaven. Customs and Practices Surrounding Holy Communion: Essays in the History of Liturgy and Culture. Kampen, The Netherlands: Kok Pharos.

Certeau, Michel de. 1982. La fable mystique: XVIe-XVIle siècle. Paris: Gallimard. English translation by Michael B. Smith. 1992. The Mystic Fable. Chicago: University of Chicago Press.

Coletti, Vittorio. 2015. "La lingua della messa." Accademia della Crusca, March 15, 2015. http://www.accademiadellacrusca.it/it/tema-del-mese/lingua-messa (accessed 29 August 2015).

Crystal, David. 1990. “A Liturgical Language in a Sociolinguistic Perspective.” In David Jasper and R. C. D. Jasper (eds.), Language and the Worship of the Church, 120-146. London: Macmillan.

Darquennes, Jeroen and Wim Vandenbussche (eds.). 2011. Sprache und Religion / Language and Religion / Langue et Religion, monographic issue of Sociolinguistica 25. Berlin and Boston: Walter de Gruyter.

Eco, Umberto. 2011. Costruire il nemico e altri scritti occasionali. Milan: Bompiani. English translation by Richard Dixon. 2012. Inventing the Enemy and Other Occasional Writings. Boston: Houghton Mifflin Harcourt.

Floch, Jean-Marie. 1984. "Pour une approche sémiotique du matériau.” In Alain Renier (ed.), Espace: Construction et signification, 77-84. Paris: Éditions de la Villette.

Fontanille, Jacques. 1989. Les Espaces subjectifs: Introduction à la sémiotique de l'observateur (discours-peinture-cinéma). Paris: Hachette.

Frisch, Karl von. 1965. Tanzsprache und Orientierung der Bienen. Berlin, Heidelberg and New York: Springer.

Greimas, Algirdas Julien. 1966. Sémantique structural: Recherche de méthode. Paris: Larousse. English translation by Daniele McDowel, Ronald Schleifer and Alan Velie, with an introduction by Ronald Schleifer. 1983. Structural Semantics: An Attempt at a Method. Lincoln: University of Nebraska Press.

Greimas, Algirdas Julien. 1970-83. Du sens: Essais sémiotiques. 2 vols. Paris: Éditions du Seuil. Partial English translation by Paul J. Perron and Frank H. Collins; foreword by Fredric Jameson; introduction by Paul J. Perron. 1987. On Meaning: Selected Writings in Semiotic Theory. Minneapolis: University of Minnesota Press.

Greimas, Algirdas J. and Joseph Courtés. 1979. Sémiotique : Dictionnaire raisonné de la théorie du langage. Paris: Hachette. English translation by Larry Crist et al. 1982. Semiotics and Language: An Analytical Dictionary. Bloomington: Indiana University Press.

Greimas, Algirdas J. and Joseph Courtés (eds.). 1986. Sémiotique: Dictionnaire raisonné de la théorie du langage. Vol. 2, Compléments, débats, propositions. Paris: Hachette. 
Hjelmslev, Luis. 1943. Omkring sprogteoriens grundlæggelse. Copenhagen: Ejnar Munksgaard. Revised English translation by Francis J. Whitfield. 1961. Prolegomena to a Theory of Language. Madison: University of Wisconsin Press.

Holt, Ron. 2006. "A Socio-Linguistic Approach to Religious Language.” Australian eJournal of Theology 6: 1-14. http://aejt.com.au/_data/assets/pdf_file/0003/395193/AEJT_6.10_ Holt.pdf (accessed 28 August 2015).

Horn, Laurence R. 2001. A Natural History of Negation. Stanford: CSLI.

Huysmans, Joris-Karl. 1884. À rebours. Paris: Charpentier. English translation by Margaret Mauldon; edited with an introduction and notes by Nicholas White. 2009. Against Nature. Oxford and New York: Oxford University Press.

Johnson, Clare. 2013. "Liturgical Intelligibility Sacrosanctum Concilium.” In Carmel Pilcher, David Orr and Elizabeth Harrington (eds.), Vatican Council II: Reforming Liturgy, 43-60. Adelaide: ATF.

Jullien, François. 1996. Traité de l'efficacité. Paris: Grasset. English translation by Janet Lloyd. 2004. A Treatise on Efficacy: Between Western and Chinese Thinking. Honolulu: University of Hawaii Press.

Keane, Webb. 1997. “Religious Language.” Annual Review of Anthropology 26: 47-71.

Keane, Webb. 2007. Christian Moderns: Freedom and Fetish in the Mission Encounter. Berkeley: University of California Press.

Lamb, Matthew L. and Matthew Levering (eds.). 2008. Vatican II: Renewal within Tradition. Oxford: Oxford University Press.

Lang, Uwe Michael. 2004. Turning towards the Lord: Orientation in Liturgical Prayer. San Francisco: Ignatius Press.

Lang, Uwe Michael. 2012. The Voice of the Church at Prayer: Reflections on Liturgy and Language. San Francisco: Ignatius Press.

Leonhardt, Jürgen. 2013. Latin: Story of a World Language. Cambridge, MA: Harvard University Press.

Leone, Massimo. 2010a. "On My Accent: Signs of Belonging in Present-Day Multicultural Societies." In Massimo Leone (ed.), Analisi delle culture: Culture dell'analisi / Analysis of Cultures: Cultures of Analysis, 415-450. Monographic issue of Lexia 5-6. Rome: Aracne.

Leone, Massimo. 2010b. "Pudibondi e spudorati: Riflessioni semiotiche sul linguaggio del corpo (s)vestito." In Rivista Italiana di Filosofia del Linguaggio 2: 74-94. Arcavacata di Rende, Cosenza, Italy: Università della Calabria.

Leone, Massimo. 2011a. "Négation et englobement." NAS: Nouveaux Actes Sémiotiques, April 19, 2011. http://revues.unilim.fr/nas/document.php?id=3889 (accessed 31 August 2015).

Leone, Massimo. 2011b. "Rituals and Routines: A Semiotic Inquiry." Chinese Semiotic Studies 5(1): $107-120$.

Leone, Massimo. 2012a. "Bacteria." In Paul Cobley, Doland Favareau and Kalevi Kull (eds.), A More Developed Sign: Advancing the Work of Jesper Hoffmeyer, 33-36. Tartu, Estonia: University of Tartu Press.

Leone, Massimo. 2012b. "From Theory to Analysis: Forethoughts on Cultural Semiotics." In Valentina Pisanty and Stefano Traini (eds.), From Analysis to Theory: Afterthoughts on the Semiotics of Culture, monographic issue of Versus 114: 23-38. Milan: Bompiani. 
Leone, Massimo. 2012c. “Libertà religiosa e significazione.” In Luigi Berzano (ed.), Credere è reato? Libertà religiosa nello Stato laico e nella società aperta, 63-75. Padua: Edizioni Messaggero.

Leone, Massimo. 2012d. "Motility, Potentiality, and Infinity: A Semiotic Hypothesis on Nature and Religion." Biosemiotics 5: 369-389.

Leone, Massimo. 2013a. Protesta / Protest, monographic issue of Lexia 13-14. Rome: Aracne. Leone, Massimo. 2013b. "The Semiotic Ideology of Semiotics: A Vertiginous Reading." Religion 43: 1-7.

Leone, Massimo. 2014a. Annunciazioni: Percorsi di semiotica della religione. 2 vols. Rome: Aracne.

Leone, Massimo. 2014b. "Détrompe l'oeil: Come disfare cose con le immagini." In Massimo Leone (ed.), Immagini efficaci / Efficacious Images, monographic issue of Lexia 17-18: 43-72. Rome: Aracne.

Leone, Massimo. 2014c. "Wrapping Transcendence: The Semiotics of Reliquaries.” In Massimo Leone and Richard J. Parmentier (eds.), Representing Transcendence, monographic issue of Signs and Society 2(S1): 49-83.

Leone, Massimo. 2015. Signatim: Profili di semiotica della cultura. Rome: Aracne.

Leone, Massimo (ed.). 2016a. Complotto / Conspiracy, monographic issue of Lexia 23-24. Rome: Aracne.

Leone, Massimo. 2016b. “On Depth: Ontological Ideologies and Semiotic Models.” In Kristian Bankov (ed.), New Semiotics: Between Tradition and Innovation. Proceedings of the 12th World Congress of Semiotics. IASS Publications \& NBU Publishing House. http://www. iass-ais.org/proceedings2014/view_lesson.php?id=48 (accessed 28 March 2016).

Leone, Massimo. 2016c. "Sémiotique de la religion: Histoire, méthode, et perspectives." In Jean-Daniel Dubois, Renée Koch Piettre and Valentine Zuber (eds.), Les sciences des religions, 7-17. Paris: EPHE.

Leone, Massimo. 2017. “Fundamentalism, Anomie, Conspiracy: Umberto Eco's Semiotics against Interpretive Irrationality." In Torkild Thellefsen and Bent Sørensen (eds.), Umberto Eco in his Own Words (Semiotics, Communication and Cognition 19), 221-9. Berlin and Boston: Walter de Gruyter.

Librandi, Rita. 2012. Lingue e testi delle riforme cattoliche in Europa e nelle Americhe (secc. XVI-XXI): Atti del Convegno internazionale (Università di Napoli “L'Orientale," 4-6 novembre 2010) (Quaderni della Rassegna 78). Florence: Francesco Cesati.

Lotman, luriī Mikhaĭlovich. 1973. Stat'i po tipologii kul'tury. Tartu, Estonia: Tartuskiĭ gos. universitet.

Lotman, luriǐ Mikhălovich. 1990. Universe of the Mind. Translated by Anne Shukman. Bloomington: Indiana University Press.

Lotman, luriǐ Mikhălovich. 2004. Semiosfera. Saint Petersburg: "Iskusstvo-SPB.”

Lukken, Gerard and Mark Searle (eds.). 1993. Semiotics and Church Architecture: Applying the Semiotics of A. J. Greimas and the Paris School to the Analysis of Church Buildings. Kampen, The Netherlands: Kok Pharos Publishing House.

Malevich, Kazimir Severinovich. 1999. Malevich on Suprematism: Six Essays 1915 to 1926. Edited and introduced by Patricia Railing. Iowa City: Museum of Art, University of lowa.

Manetti, Giovanni. 2008. L'enunciazione: Dalla svolta comunicativa ai nuovi media. Milan: Mondadori università. 
Maran, Timo, Dario Martinelli, and Aleksei Turovski (eds.). 2011. Readings in Zoosemiotics. Berlin and Boston: Mouton De Gruyter.

Petit, Philippe. 1997. Traité du funambulisme. Arles: Actes Sud.

Rambelli, Fabio. 2013. A Buddhist Theory of Semiotics: Signs, Ontology, and Salvation in Japanese Esoteric Buddhism. London and New York: Bloomsbury Academic.

Robinson, Andrew J. N. 2010. God and the World of Signs: Trinity, Evolution, and the Metaphysical Semiotics of C. S. Peirce. Leiden and Boston: Brill.

Sandino, Linda. 2004. "Here Today, Gone Tomorrow: Transient Materiality in Contemporary Cultural Artefacts." Journal of Design History 17(3): 283-293.

Saussure, Ferdinand de. 1972. Cours de linguistique générale. Edited by Tullio de Mauro. Paris: Payot.

Schloeder, Steven J. 1998. Architecture in Communion: Implementing the Second Vatican Council Through Liturgy and Architecture. San Francisco: Ignatius Press.

Sebeok, Thomas A. 1990. Essays in Zoosemiotics. Toronto: Toronto Semiotic Circle.

Shatskikh, Aleksandra. 2012. Black Square: Malevich and the Origin of Suprematism. Translated by Marian Schwartz. New Haven: Yale University Press.

Van Tongeren, Louis and Charles Caspers (eds.). 1994. Per Visibilia ad Invisibilia: Anthropological, Theological, and Semiotic Studies on the Liturgy and the Sacraments. Kampen, The Netherlands: Kok Pharos.

Venable, Shannon L. 2011. Gold: A Cultural Encyclopedia. Santa Barbara: ABC-CLIO.

Vincie, Catherine. 2013. "The Divine Office in the Contemporary Church.” In Carmel Pilcher, David Orr and Elizabeth Harrington (eds.), Vatican Council II: Reforming Liturgy, 189-202. Adelaide: ATF.

Volli, Ugo. 2016. "Il velo di Mosè e altri filtri ottici nella Bibbia ebraica." In Massimo Leone, Henri de Riedmatten and Victor I. Stoichita (eds.), Il sistema del velo / Système du voile, 229-261. Rome: Aracne.

Waquet, Françoise. 1998. Le latin ou L'empire d'un signe: XVIe-XXe siècle. Paris: A. Michel. English translation by John Howe. 2001. Latin, or, The Empire of the Sign: From the Sixteenth to the Twentieth Century. London and New York: Verso.

West, Cornel. 2004. Democracy Matters: Winning the Fight against Imperialism. New York: Penguin Press.

Yelle, Robert A. 2013. Semiotics of Religion: Signs of the Sacred in History. London and New York: Bloomsbury. 
